\title{
Operações metonímicas e metafóricas na inscri- ção do nome próprio
}

\author{
Leandro Dieter
}

RESUMO: On peut lire entre les lignes, dans l'écriture du nom et dans ses déroulements, ce qui une écriture non-consciente - qui ne se soutien comme exercice d'une réflexion - revèle sur les procedes de création de la culture et d'um sujet, atravers la passade réalisée parmi la transmission d'um nom propre, à l'appropriation d'um sujet par le nom. J'analyse, avec la teorie freudolacaniene, l'articulation des noms qui quelqu'um apporte et, donc, la façon d'apercevoir sa place dans um système familier, avec sa respective insertion dans au lieu sociaux. On commence à partir de l'étude des cas du la clinique psycanalitique, sourtout de deux garçons, qui réalisant des différents opérations, métonymiques et métaphoriques, avec les nom-de-mère et avec le nomde-père em etablir quelque chose de propre au nom.

PAlaVRAS-CHAVE: Inscrição Psíquica; Nome Próprio; Psicanálise; Metonimia e Metáfora.

Talvez mais do que em qualquer época, a criança é convocada a responder por seu nome, quando ela precisa sustentá-lo na escrita. Escrita que, quem sabe, estabilizará o próprio sujeito naqueles caracteres. Ao dar lugar às letras de seu nome, é o sujeito mesmo que articula a si e aos seus em um encadeamento em que as leis da linguagem são o cenário. Convém ressaltar que quando me refiro à escrita não a tomo como um exercício atrelado ao período escolar. Quando, por exemplo, uma menina de vinte meses faz um traço na folha, até então em branco, ilumina-se ao me mostrar sua produção, só a tempo de fazer mais um, outro e outro, cada traço destes

Leandro Dieter é psicólogo do CAPS-I da Prefeitura Municipal de Novo Hamburgo, psicanalista, doutorando no ILETRAS/UFRGS. 
muito próximo a todos os anteriores, mas ao mesmo tempo únicos, tal o seu júbilo quando os mostrava. Ela já não mais está perdida na indiferenciação da folha em branco, pois consegue, de forma rudimentar, é verdade, mas instauradora, constituir um traço de escrita desde onde ela começa a se contar. Celebramos o surgimento dos traços que as crianças vão estabelecendo como materialização de si mesmas. Como se na representação que vão fazendo, elas mesmas fossem saindo de uma indiferenciação para a qual ainda corríamos o risco de perde-las. Traços no papel, na parede, no próprio corpo, não importa a superfície, vão se configurando até formarem uma assinatura, assinando embaixo a procuração passada. Cada ensaio de escrita que uma criança produz em um determinado momento revela as operações lógicas com as quais está envolvida em seu exercício de inscrição na linguagem. Se isso é verdade, será justamente quando falta, sobra ou, enfim, algo está fora do lugar na escrita do nome próprio, que encontramos um momento privilegiado para pensar sobre as operações em jogo na inscrição do sujeito na linguagem.

Um dos caminhos possíveis ao deparar-mo-nos com uma falta no nome é a de realizar uma obturação, preenchendo e fazendo, proteticamente, escrever certo. Proponho, ao contrário, suspender, elevar o lapso em torno da escrita do nome próprio como privilegiado para situar que, se o escrevente é servente da língua - e, portanto, não é capaz de esgotá-la enquanto objeto de reflexão - o sujeito pode assinar embaixo da escrita que o constitui. Ou seja, justamente ao não atender a demanda que pretende a eliminação do sintoma, se possibilita, não só a sua resolução, mas o anúncio de um sujeito do inconsciente que reinventa as leis que o sustentam na linguagem.

Um nome costuma nos ser atribuído mesmo antes de surgirmos enquanto materialidade corpórea, antecipando-nos e configurando um lugar a ser ocupado. Apesar de carregarmos um nome oficial, recebemos ao longo da vida denominações mutantes, somos convocados a responder, nos diferentes grupos dos quais participamos e na especificidade dos vínculos mais restritos, a um chamado peculiar. Vez ou outra, ainda podemos nos surpreender quando, vindo diretamente da infância, uma voz recupera um apelido ao qual, apesar do caráter anacrônico que apresenta agora, respondemos impensadamente. Estamos, então, sujeitos a diferentes alcunhas, marcas que nos foram superpostas, que nos engancham de forma enigmática às origens.

O código Civil Brasileiro é pouco prescritivo em relação às formas pelas quais o nome deve ser formado e prevê, somente, "quando o declarante [da Certidão de Nascimento] não indicar o nome completo, o oficial lan- çará adiante do prenome escolhido o nome do pai, e, na falta, o da mãe". Neste mesmo artigo, em parágrafo único, talvez a restrição mais explícita na construcão do nome, refere: "os oficiais do registro civil não registrarão prenomes suscetíveis de expor ao ridículo seus portadores”. Se não há nenhuma regulamentação mais precisa em relação ao nome na legislação brasileira, à que lei estamos remetidos quando atribuímos um nome a alguém? As inúmeras possibilidades na construção do nome, a opção por tomar um e/ou outro nome de família ou mesmo inventar um sobrenome indicariam, como afirma Ângela Jesuíno-Ferreto (1991), uma fragilização da dimensão simbólica [no Brasil?], onde o nome próprio não seria capaz de inserir o sujeito numa linhagem?

Em um texto eletrônico, Petit dialogue sur la transmission du patronyme ${ }^{2}$, os franceses também depararam-se com a proposta de mudança no Código Civil que prevê uma flexibilização na transmissão do nome, autorizando que ele possa ser realizado do lado da mãe, do pai ou dos dois lados. "A lei antiga tinha a vantagem de ser simples; com o nome do pai tudo estava dito. A nova lei não é mais imperativa. Ela permite a escolha". Quais as implicações destas mudanças na lei civil para a questão da transmissão simbólica do nome, ou antes talvez, a quais alterações na estrutura de transmissão simbólica do nome encontradas na cultura - onde o nome do pai opera em falta - a lei civil vem fazer eco?

Everton, um rapaz de 12 anos, escuta de sua professora, em função da bagunça recorrente e do quanto seu comportamento contrastava com sua irmã, reconhecidamente boa aluna: - tu não pode ser irmão da Maria. Considera essa fala como oracular, a expressão de sua verdade, e passa a indagar seus pais sobre a razão de nunca terem-Ihe revelado que não era seu filho. A partir daí, relatos precisos de sua história, fotos, nada parecia suficiente para dar-lhe prova de sua filiação. As dificuldades na escola ampliam-se, culminando com o ato de urinar no lixo da sala de aula, o que produz uma suspensão da escola por um mês. A professora traduziu em palavras o que para ele já fazia questão: não faria jus a carregar um sobrenome. Precisou mijar no lixo como forma de inscrever sua marca. Contudo, ele apresenta seu nome na Certidão de Nascimento, completo, com o mesmo sobrenome dos irmãos, proveniente do pai. Não se trata, portanto, de um impasse colocado na identidade cartorial, apesar dela, às vezes, fazer ressoar efeitos indeléveis sobre quem suporta um nome.

Na transmissão do nome fica-se, em parte, submetido a um aspecto

'Lei no 6015, de 31 de dezembro de 1973, artigo 55.

${ }^{2}$ Texto assinado por Jeans Périn de 22/032003 e encontrado no endereço Freud-lacan.com.

Organon, Porto Alegre, $n^{\circ}$ 40/41, janeiro-dezembro, 2006, p. 77-91 
imaginário. Ao reduplicar e materializar uma experiência já perdida, o (pré)nome é convocado a preencher, miticamente, o que faz falta àquele que nomeia, fixando-lhe um sentido. ${ }^{3}$ A escolha do nome surge, muitas vezes, como tributo de uma identificação. O nome de um ator ou atriz pronunciado em algum filme ou novela, o nome de um colega de escola do qual nos lembramos sem mesmo saber por que, um antepassado, alguém que morreu ou ainda, um gesto que uma pessoa teve conosco e que ficou impresso, são recuperados na identificação, através de um pequeno traço que representa o outro. Ao nomear, estamos, então, remetidos a um aspecto imaginário, onde tentamos reduplicar e materializar uma experiência já perdida. Francisco Martins (1991), no livro O Nome Próprio, diz que “o prenome seria mesmo uma superfície sobre a qual os pais projetariam a imagem sonhada de uma criança ligada a um mito familiar" [MARTINS, 1991, p. 125]. É para dar conta de uma falta, recobrindo-a, que o prenome surge, convocado a preencher, miticamente, o que faz falta àquele que nomeia. O efeito do prenome estaria ligado, essencialmente, à produção de um "Eu", sustentação de um narcisismo primário e base para que algo de um sujeito subsista. Martins compreende bem que se não fosse a possibilidade aberta pelo prenome na singularização do sujeito entre os seus, "os nomes próprios não passariam de simulacros". [Ibid. p.135] Contudo, se o nome permanece respondendo meramente a uma idealização que recai sobre ele, o nome aprisiona e singulariza aquele que o porta numa alienação ao desejo do outro.

Em um registro simbólico o lugar de cada um não precisa fazer sentido pois está remetido à lei que o nome-de-família estabelece e é a sua referência o que permite ao sujeito não ficar completamente à mercê das imagens que provém dos que o circundam e poderiam invadi-lo, através de sucessivas re/nomeações (questão na psicose). O nome de família envia a uma demarcação das fronteiras entre um dentro da família e um fora dela e concede um signo de sustentação do sujeito no espaço público. Entretanto, como bem observou Francisco Martins, "existe a possibilidade de o sujeito ser colocado exposto, já que não existe patronímico que proteja de tudo e de todos". [Ibid.p.144] Percebe-se, então, que nas formas de transmissão do nome pode haver sempre uma falha e algo de uma insuficiência simbólica. Nesta medida parece-me crucial pensar o nome, também, no estatuto do que está além do imaginário e do simbó-

${ }^{3}$ Também é do registro imaginário supor que a escrita de um nome pouco usual possa representar, para quem o escreve, maiores dificuldades. lico e que nos torna a todos, de uma ou outra maneira, expostos. ${ }^{4}$

Atribuir um nome a alguém, portanto, sempre realiza o exercício da nomeação do inominável. Quando algo de um nome falta, ele acaba retornando, em outro lugar. Ao ler um texto que resiste à nossa entrada, podemos lê-lo em voz alta, assim tomando a devida distância, impedindo que sejamos absorvidos pelo excesso da letra, que, em sua imagem, nos captura, ou pela ausência das letras, quando elas desfilam sob nossa vista sem que as olhemos efetivamente. Se sobre a letra pode recair um excesso de imaginarização, quando afirmamos esta letra é minha, a letra, por outro lado, revela de si a barra do recalque, surge borrada quando comparece sem qualquer significação, completamente idêntica a si mesma. A letra, enquanto instância no inconsciente, apresenta este caráter paradoxal, à medida que se apresenta com um caráter material, suportado por um traço ou por uma letra tipográfica até, e, ao mesmo tempo, destituída de toda representação. Por isso mesmo, a letra é a repetição daquilo que não pode nunca comparecer, aparecendo, então, apagada. Como ler o que está apagado? Ouvindo a escrita e lendo a fala. Na escrita é preciso, para ler, poder ouvir as ressonâncias da homofonia e, ao ouvir, é necessário colocar o som como letra, corporificado. Nas duas vertentes, é de uma leitura que se trata, "leitura do que se ouve de significante." [LACAN, 1972-1973, p.47] A leitura da letra, que o significante, em seus desdobramentos metonímicos ou metafóricos vêm contornar, é o permitirá o que nomeio como ex-crição de sujeito. Penso a ex-crição como a operação da ordem da letra no inconsciente, repercutindo na letra escrita, da qual um sujeito pode advir ao realizar novas versões de pertença a sua filiação, ressignificando seu legado. $\hat{E}$ a leitura da letra, realizada desde fora, que produz a inscrição de um próprio ao nome na escrita do nome próprio. Através desses elementos materiais e localizados, podemos entreler o sujeito em sua inscrição psíquica. O sujeito a que me refiro é efeito da inscrição que se realiza. Inscrição de sujeito, mas sujeito da inscrição.

Um primeiro recorte clínico talvez possa auxiliar a explicitar melhor a forma que o nome adquire, ao longo de três gerações, o seu desdobramento na linha do tempo, o que irá demonstrar, em um eixo diacrônico, estruturas de transmissão do nome próprio e a apropriação do próprio nome.

Recebo, pela primeira vez, uma criança de oito anos como paciente identificado e seus pais. Eles falam que Matias "engole as letras e acrescenta outras" e que está repetindo a primeira série. Pergunto então ao menino se

${ }^{4}$ Criança que foi abandonada pelos pais, ao nascer ou em tenra idade, e colocada na roda dos expostos (DHLP). 
ele poderia escrever seu nome $e^{5}$ no quadro branco, com o que concorda rapidamente. Ele escreve: Matias de Mill Pelal (cf. fig.1 abaixo), enquanto seu nome é Matias de Millo Pedreira. Enquanto Matias está ao quadro, $\mathrm{He}$ lena, referindo-se à educação dada à filha, comenta que a fez "comer o alfabeto". Disseram-lhe que havia sido muito severa com ela e aí "aliviou com Matias". Apesar disso, enquanto Matias está escrevendo seu nome, a mãe vai corrigindo-o.

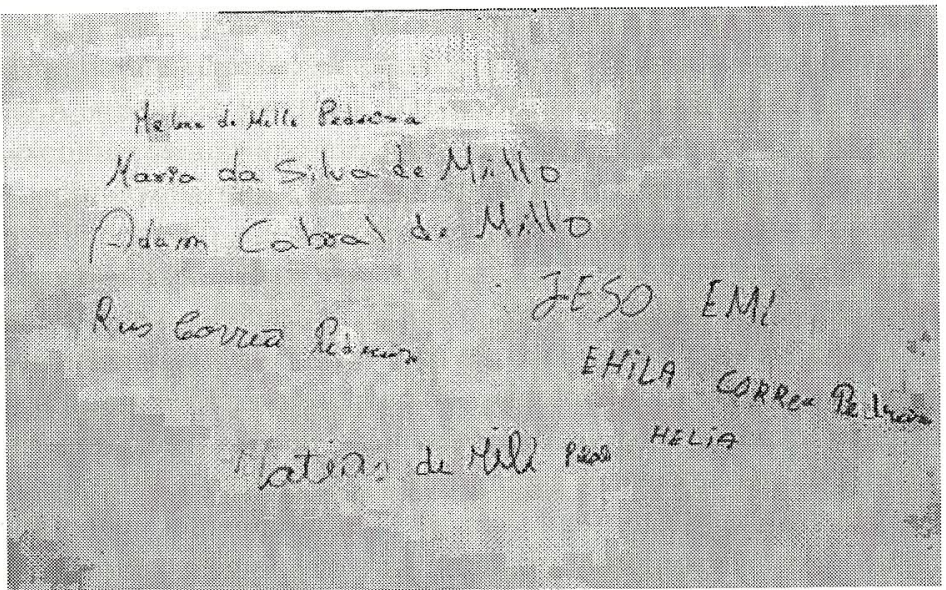

Fig. 1

Pergunto se os pais podem escrever seus próprios nomes e os nomes de seus pais. A mãe, prontamente, ergue-se e escreve seu nome no topo do quadro. A seguir, abaixo, o nome da mãe e o nome de seu pai, todos completos e legíveis. Enquanto a mãe escreve, o pai diz que só sabe escrever o seu nome. Mesmo assim, peço que escreva o nome dos seus pais à sua maneira. Escreve o nome de seu pai parcialmente, trocando as vogais de seu primeiro nome, três letras iniciais do segundo nome - sobrenome do lado materno - e, omitindo completamente o último nome, sobrenome do lado paterno. Ao escrever o nome de sua mãe, Ruis inverte as duas primeiras letras do prenome, mas acrescenta o seu "sobrenome de casa" e o "sobrenome de casada," com-" pletos e escritos corretamente.

${ }^{5}$ Reconstruí, seu nome e de sua família preservando sua identidade e, ao mesmo tempo garantindo a permanência dos elementos formais importantes para a análise.
O que impediu a escrita do sobrenome Pedreira do lado paterno, de onde ele provém, e seu surgimento do lado materno? Ocorre um apagamento do sobre-nome-do-pai ${ }^{6}$ e seu deslocamento integral para o lado da mãe, que reivindica o nome do pai, tornando-o comum. Para Ruis, aquilo que se encontra sobre-o-nome-do-pai, do pai enquanto metáfora, é deslocado, ocupando lugar ao lado da mãe. A transmissão do que estava sobre-o-nome se dá, então, através dos restos metonímicos que o nome-da-mãe oferece.

A esposa de Ruis aponta o equívoco na inversão das duas primeiras letras na escrita do prenome da mãe do marido e lhe alcança a carteira de identidade, que se encontrava em sua bolsa. Ruis copia o nome de sua mãe, agora corretamente. Também com Helena está a carteira de identidade de Matias - ela conta que, ao fazê-la, o filho não conseguiu assinar seu nome e precisou colocar o "dedão". O nome do pai de Ruis também fica mais apagado em relação a como escreve o nome da mãe.

O maior esmero na escrita do nome da mãe revela-se mais tarde, sob outra forma, na sessão, quando Ruis chora ao se lembrar da mãe, falando sobre sua morte (há cinco anos) e sobre como ela tinha sido importante para ele. Nesse momento, Matias fica ao seu lado, impressionado com o lamento do pai. Esse homem teve dois acidentes vasculares cerebrais no ano anterior e um, quatro meses antes da consulta. Helena, ao ver marido e filho um ao lado do outro, diz que os filhos são mais "ligados" ao pai, como se eles "não tivessem mãe". Ela é quem se toma no lugar da falta, a quem, portanto, nada falta.

Como podemos ler o que está aí escrito? A "presença" reivindicada aqui é a da mãe, anunciada mais ainda quando refere o quanto seus filhos não têm mãe! Trata-se da presença do que é impossível representar e que se repete no retorno de sua letra. A escrita do nome de Ruis e Matias depende do que está na bolsa de Helena, de onde sai a letra em torno da qual pai e filho se situam. Segui-la textualmente implica uma alienação à letra que a mãe encarna. Ela é quem de/tém a letra. Se alguma letra cai na escrita do nome do pai e do filho, Helena coloca-se na posição daquele que, ao vislumbrar a falta no outro, goza com a possibilidade de que é ela quem tem aquilo que o outro demanda: a certeza de

${ }^{6}$ Quando utilizo nome-do-pai ou nome-da-mãe com hífen é para marcar um significante. Aqui, especificamente, introduzo, sobre-nome-do-pai para demarcar aquilo que antecede o pai e que lhe dá um lugar na linhagem e a incumbência que toda herança implica de se haver com a sua transmissão. 
que em sua bolsa está a letra que pode ser lida. Com isso, desloca para o filho a letra como puro real, impossível de atribuir sentido e que não cessa de se reproduzir. Furta-se, em termos, à castração que sustenta a função simbólica no âmbito metafórico, mas permite, pela via do deslocamento metonímico, a prevalência de uma letra sob a qual já pode incidir uma produção de sentido.

Digo em termos, pois como é evidente, não se trata aqui de uma psicose, mas de uma neurose, em que já muito do real pode ser tomado como enigma e pode ser simbolizado. Aquilo que não foi, contudo, encontra no mecanismo do deslocamento a via de re/atualização, quando certas letras acabam adquirindo uma prevalência, inserindo-se repetidas vezes na escrita de outros nomes. Prevalência do nome-da-mãe incidindo tanto sobre Ruis quanto sobre Matias.

O nome próprio é a maneira singular com que cada um tenta elaborar as circunstâncias da articulação do nome da mãe com o nome do pai. O sobrenome do lado do pai é escrito por Matias como Pedlal. A letra " $R$ " é omitida por duas vezes e, em seu lugar, surge o "L". Há uma reduplicação da letra "L" do nome da mãe ao lado do nome do pai, uma prevalência da Letra " $L$ " no lugar de " $R$ ", que também é a inicial do prenome do pai. O que lhe faz, nesse momento, inacessivel à letra do pai? O nome-do-pai está em falta! Ele reaparece de duas formas diferentes: uma quando surge do lado do nome da mãe do pai de Matias, ${ }^{7}$ - produzindo uma certa desvalorização da função que o pai de nome tem, e de sua incidência tanto sobre o filho quanto sobre a sua mulher - e, de outra forma, através dos restos metonímicos ${ }^{8}$ que são convocados a reconstituir a falta do nome.

Matias mostra na escola e em casa quando ganha algo do pai, dando muita ênfase a isso, o que faz seus colegas o chamarem de "filhinho do papai." Ao mesmo tempo, faz questão de mostrar o que ganha e acaba perdendo o que recebeu, tomado por um outro. Assim aconteceu com um lápis recebido do pai, onde este havia gravado suas iniciais - Matias P.: um colega quebrou-o e ficou com a parte sem marcas.

Matias tem um saco de brinquedos velhos e quebrados. Pede muito do pai que lhe compre novos objetos. Os filhos - a filha tem 14 anos, Matias 8 - ganham R \$5,00 de mesada; tem que ser igual, diz o pai, inclusive a nota

Lembrem Saussure quando diz: "o valor de um termo pode modificar-se (...) unicamente pelo fato de um termo vizinho ter sofrido uma modificação".

pelo fato de um termo vizinho ter sofrido uma modificação".
${ }^{8}$ Quando a letra "L" preponderante no nome-da-mãe, surge no lugar da letra "R" do nome-do-pai. (não pode um, por exemplo, ganhar 5 notas de $\mathrm{R} \$ 1,00$ enquanto o outro ganha uma de $\mathrm{R} \$ 5,00)$. Quando chamo atenção sobre as idades, o pai diz: não pode ter diferença! Ele se considera muito zeloso com os filhos e, para ilustrar, conta uma situação no ônibus em que um senhor queria tirar Matias do banco para poder sentar e Ruis disse, um tanto ofendido, que Matias também pagara passagem, recusando ceder o espaço do filho. Enquanto Ruis dá passagem ao filho, o filho paradoxalmente perde o passo, pois só poderá efetivamente contar-se, reconhecer-se, quando for pelo sobre-onome-do-pai, des/contado.

O pai, excessivamente cuidadoso, não opera a diferença sexual que poderia auferir ao filho uma marca suficiente para que não precisasse sempre novamente de outro objeto, em um sucessivo deslocamento. Há, contudo, uma marca em que Matias pode se amparar, que serve para, em parte, interditar seu colega quando este não toma o pedaço do lápis já marcado com o nome que o pai de Matias escreveu. Se a inscrição paterna lhe permite um lastro a partir do qual não é completamente invadido pela indiscrição do colega, esse rastro do pai precisa sempre ser atualizado e certificado, presentificando incessantemente que aquele registro ainda não é suficiente para ser reconhecido e, portanto, obtura-o proteticamente com a letra do nome-da-mãe.

Enquanto o pai fala, agora sobre si, refere como ficou alguns dias com o lado direito do corpo paralisado quando esteve no hospital, e viu, "apavorado", pessoas saindo cobertas com um pano. Enquanto isso, Matias desenha o Saci Pererê e uma cobra, dizendo: "a cobra vai comer o Saci Pererê." Curiosamente, Pererê realiza uma homofonia com o sobrenome do lado do pai que, na construção do desenho, assim como anteriormente na construção da letra na escrita do nome, alguém comeu! Mas, mais do que isso, o que se anuncia aqui é o quanto e como o pai enfrenta a morte. E Matias faz isto através de uma metáfora, que pode ou não ser lida. Quem nesse momento aparece enquanto manco é o pai, que refere o quanto, paralisado e impotente, vê a morte desfilar a sua frente.

A conexão entre um significante e outro, que a metonímia realiza, institui os objetos e as letras de valor, desvalorizando o sentido. Se o valor atribuído nunca é suficiente para haver uma detenção do sujeito no momento de criação de uma significação, é, na medida em que falta ao operador do nome-do-pai consistência, porque o pai não suporta essa função. No lugar da metáfora do nome-do-pai, o pai apresenta-se enquanto metonímia que o nome-da-mãe permite, ao oferecer ao filho sempre outro valor. Aquilo que é ofertado, contudo, está destituído de valor suficiente 
para inscrever no sujeito o próprio ao nome, porque aquele que oferta não está se havendo com a castração que a morte e a sexualidade impõe. Matias tenta, através da produção da metáfora do Saci Pererê, por exemplo, a instauração de um pai que, apesar de manco, possa estabelecer marcas, entre elas sobretudo, a de um nome. Desse ponto, em que se pode entreler uma nova significação em jogo sobre o eixo do deslocamento metonímico, abrese, como que num hipertexto, outra coordenada.

Quando Matias escreve o nome-da-mãe como MILLO, sem o zero, tomando-o enquanto "o significante da falta desse símbolo zero", [LACAN, (1960) 1998, p.836] institui-se o significante de uma falta no Outro, que poderia facultá-lo a lançar-se, então, a dar conta desse indescritível ou indescrevível nome-do-pai. É nesse lugar, se pensamos o eixo diacrônico como uma combinação de significantes, que um se desloca descolando o outro, o ponto de ancoragem e ultrapassagem para o eixo sincrônico, terreno em que a ficção poderia tornar-se possível. O ponto de desvio no deslizamento horizontal dos termos em jogo na construção do nome próprio abre-se a um hipertexto, quando encontra na falta desse zero, no eixo vertical da metáfora, a possibilidade de inscrição do próprio nome. $\mathrm{O}$ deslocamento metonímico, se necessário, não é suficiente para permitir a constituição do próprio nome, como neste recorte clínico, em que a invenção do nome-do-pai fica como uma promessa.

É, contudo, no eixo do deslocamento que se realiza uma torção fundamental, para a constituição de um sujeito, com o operador nome-da-mãe. Passa-se de uma extensão metonímica, onde o nome-da-mãe se adensa e multiplica os efeitos de sua letra, para uma redução metonímica. É o que podemos demonstrar com dois recortes de um outro menino de 8 anos que nos chegou para atendimento pois, sobretudo quando a professora titular ausentava-se da sala, chorava, pedia socorro e fugia para a rua sem rumo. ${ }^{9}$ Em um desenho que vai ocupando todo o espaço do quadro e onde ainda não há muito espaço para o vazio que pudesse separar as pala-

9 Sua mãe relaciona a situação à falta do pai, que vai "visitá-los", normalmente, a cada final de semana. Atualmente, ela o recebe do lado de fora da casa e diz não estar mais disponível e que não espera mais nada dele. Mário, vamos chamá-lo assim, diz: "a mãe tropeçou por causa do pai". Pergunto se o pai passou a perna na mãe?! Ela sempre recebeu as visitas desse homem, com quem tem outra filha, seis anos mais velha que Mário, mas nunca residiram juntos. Ela, que ñ̃o faia ma

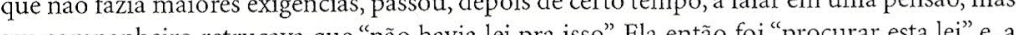
seu companheiro retrucava que "não havia lei pra isso". Ela então foi "procurar esta lei" e, a partir do instante em que o intimou frente à justiça para reivindicar a legitimação do vínculo e a inclusão do nome do pai ao de seus filhos, não se interessa mais por ele. Mário carrega o nome do pai a cerca de três anos. vras e dar lugar a um sujeito que nomeia, o exercício crucial ao qual se lança fica em torno do desdobramento dessa amálgama que se produz em "mamãemário."10

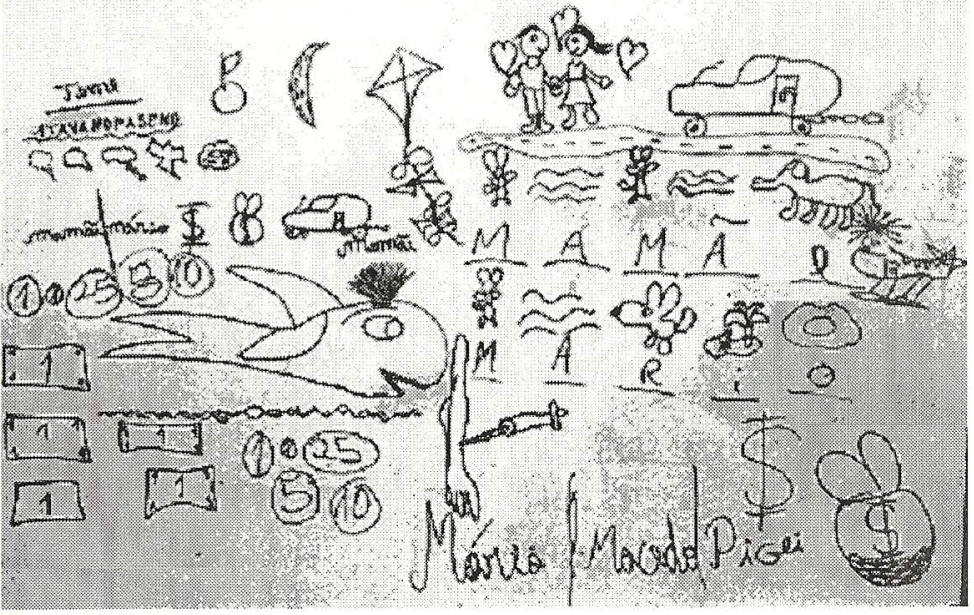

Fig. 2

Ele circula por uma série de formas diferentes de inscrição, a escrita, o desenho e o ideograma, onde tenta responder ao enigma que sua mãe lhe coloca ao dizer que não se interessa mais por ninguém mas que "só Mário importa." Mário, contudo, somente conseguirá entrar na linguagem, ou seja, respeitando as leis que ela nos impõe, no momento em que houver a desvalorização, através de uma redução metonímica do nome-da-mãe. Somente então, como Saussure nos ensinou com a teoria do valor, Mário pode dirigirse ao operador nome-do-pai o que lhe permite acesso às trocas simbólicas.

Mário desenha um grande olho, uma boca com a língua saliente e dois braços abertos para o alto e diz, dirigindo-se a mim: "estou de otho no senhor!" No meio dessa figura, escreve seu prenome, a primeira letra do nome de família materno e o sobrenome do pai com a omissão de uma letra. Sua mãe chama a atenção sobre a falta, comentando que o pai pediu-lhe para escrever o sobrenome paterno.

${ }^{10} \mathrm{~A}$ barra interposta aí sou eu quem faço, o que, depois, desdobra-se em sua primeira assinatura onde ele, por sua vez, também interpôe uma separação a cada nome. 


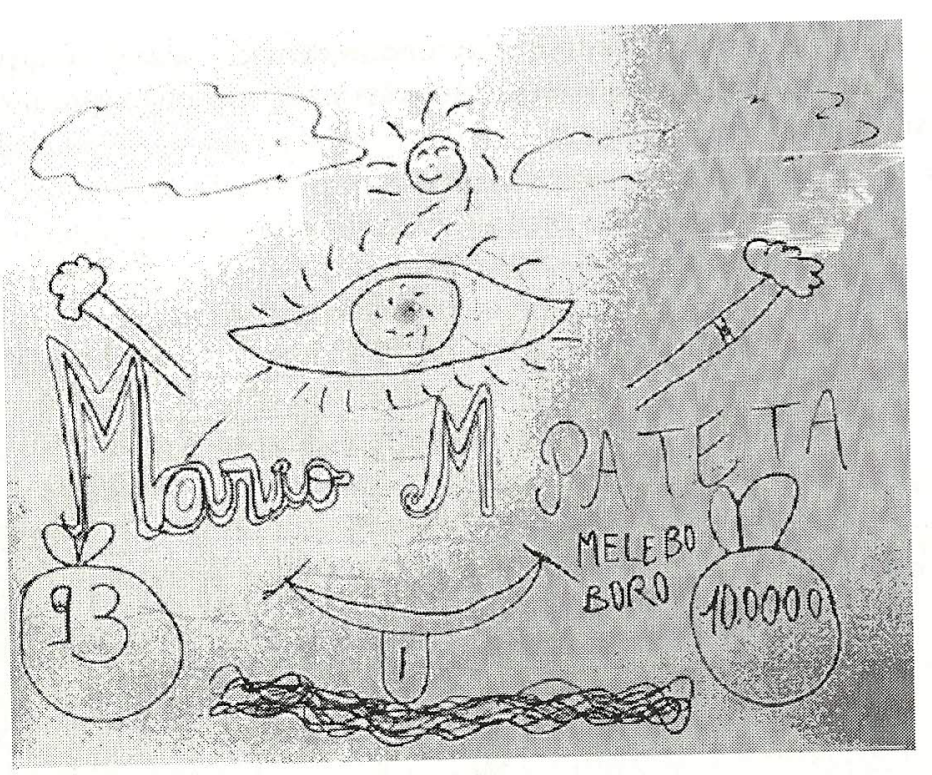

Fig. 3

Mário apaga então o sobrenome do pai e inicia a escrevê-lo novamente pela letra $P$, mas acrescentando agora ateta...pateta. Abaixo do sobrenome do pai, agora transformado em pateta, escreve (em outra cor) MELEBO (com maiúsculas) e mais uma vez abaixo, BORO. Solicito que leia o que escreveu e diz: "MELECA" e "BURRO". Estamos aqui frente a duas formas de escrita do nome próprio. A primeira apresenta-se num eixo horizontal, no deslizamento dos termos em jogo. A letra " $M$ ", letra inicial do sobrenome materno, está deslocada, e ocupa o lugar do sobrenome, ele mesmo. Sobre o nome da mãe, recai uma operação metonímica que toma a parte "M" pelo todo-nome. Através dos exercícios em seu nome próprio, ele opera a criação de um próprio ao nome. O nome da mãe é reduzido a uma letra! Se antes havia se lançado assiduamente no exercício de escrita em seu nome próprio buscando uma diferenciação entre mamãemário, agora pode realizar uma operação de redução em seu nome. Assim, dá nome ao significante da falta no grande Outro materno. É essa redução do nome-da-mãe que permite, posteriormente, ocupar-se com operações em torno do nomedo-pai. Se, desde o início, Mário ensaiava como ele mesmo poderia articular-se perante esse nome da mãe, que de tão excessivo lhe ficava colado, agora, com sua redução, instaura-o enquanto significante nome-da-mãe, permutável e irremediavelmente remetido a outro significante, sobre o qual ele se debruça tentando entender do que se trata.

Ao escrever o sobrenome paterno com uma letra que falta - o que é observado pela mãe, atenta para aquilo que, no pai, não comparece - e mostrando, depois, que é capaz de voltar-se sobre o nome do pai, escrevendo-o de outras formas, Mário demonstra o quanto algo de uma transmissão se efetiva. "É enquanto que uma destas letras está ausente que as outras funcionam, mas que sem dúvida é na sua falta que reside toda a fecundidade da operação". [LACAN, (1966-1967), Aula de 23 de novembro de 1966] A primeira forma com que o nome-do-pai pode ser retranscrita acontece em um eixo diacrônico, de contigüidade, em que há uma combinação com outros significantes postos à disposição pela mãe, que referiam o pai como "um poste", por exemplo. "P", primeira letra do sobrenome do pai, deslocase para Pateta. A letra que falta no nome-do-pai não o impede de escrever, mas é justamente aquilo que no pai faz falta que permite o exercício de seu preenchimento. Assim, na tentativa de apropriação que há na escrita do nome próprio, o nome-do-pai, último nome, é o ponto de basta. ${ }^{1}$

$\mathrm{Na}$ escrita de seu nome próprio, Mário indica, quando escreve PATETA, que ele mesmo pode apropriar-se do próprio em seu nome ao tomar a significação que circulava, dando-lhe nome. A desvalorização do sentido, que a metonímia concede, permite, nessa renomeação e invenção do pai como um pateta (o que não foi dito pela mãe, literalmente), que Mário já possa servir-se do nome-do-pai, constituindo algo de um próprio ao nome. Assim, tomando o significante nome-do-pai como sustentando a falta que o constitui, Mário pode, ao deslizar como desejante, nomear a falta de ser, aquilo que não é. Ele não é PATETA! Apesar disso, não ser pouca coisa, na metonímia há uma "manutenção da barra" [LACAN, (1957) 1998, p.519] que separa $S / s$, o significante do significado, o que tem como consequêencia a escrita de um nome ainda muito preso em sua herança.

Ainda outro movimento precisa ser realizado para inventar um próprio ao nome. No desenho, uma outra forma de escrita do nome próprio surge quando Mário rompe o eixo horizontal, mais usual, e transita numa perspectiva vertical ao escrever o seu nome com os significantes do nome-damãe e do nome-do-pai, produzindo a emergência de uma nova significação.

Ao escrever MELEBO, repete do sobrenome materno as seguintes letras: $\mathrm{M}_{-} \mathrm{E}_{-} \mathrm{O}$. Além disso, as consoantes de ligação apresentam sons bastante próximos ao seu sobrenome materno. No hipertexto que essa escrita inaugura, o nome-da-mãe é lido por ele como uma MELECA, nessa

"Mesmo quando este nome, eventualmente, não se encontra, formalmente, no nome próprio. 
enunciação, demonstra que as chances para ficar grudado nela já são muito menores. O segundo nome escrito foi BORO e lido como BURRO. Ao ler a expressão $B O R O, O B$ soa mudo e persiste a ressonância de ORO. Se o pai é um pateta ou um burro, é do lado do nome-do-pai que se encontra o $\mathrm{O}(\mathrm{U}) \mathrm{RO}$, o teso(u)ro que Mário insiste em desenhar, representado como sacos de dinheiro ou simplesmente sacos com números. Como resolver esse dilema de um pai burro que, ao mesmo tempo, guarda tal valor? Leio para ele minha versão de BORO, dizendo: ORO?! O burro tem um teso(u)ro? Mário passa a enumerar que o pai planta melancia, batata, aipim, couve, alface...Digo, então, que as sementes do Guido estão dando frutos.

Se me permito estabelecer uma leitura do que ele propõe, é na medida em que Mário se encontra nesse momento da escrita do nome e na leitura que faz dela, na estrutura da metáfora, pois “é na substituição do significante pelo significante que se produz um efeito de significação que é de poesia ou criação". [LACAN, (1957) 1998, p.519] Ele toma o nome-da-mãe e inventa um significante MELECA para substituí-lo. Quando apresenta BORO no lugar do nome-do-pai - último nome no eixo vertical - ele lê burro, em uma quase replicação do deslocamento que havia já realizado na metonímia PATETA. Contudo, a letra, instância da letra no inconsciente que Mário oferece à leitura daquele em quem está de olho, impõe que se tome o "momento de ciframento do traço, que só pode ser acústico" [Balbo. Do ouvido ao olho, p.59] como uma metáfora. Parte-se de uma correspondência do som à escrita. Somente recorrendo-se à letra, à textualidade do escrito, ultrapassando o que parecia um tropeço ou um defeituoso acesso à ortografia, para verificarmos que o sujeito já está aí inscrito nas leis da linguagem. Não se trata de corrigir e fazer escrever certo, mas de entender que, invariavelmente, os equívocos tem uma razão de ser; basta que possamos lê-los. Ao permitir, assim, que o nome-do-pai seja tomado como valioso, subverte o lugar que the era predominantemente atribuído no discurso que circulava. Realiza a ultra / passagem do nome-do-pai quando vai além dos limites impostos por uma significação que o circunscrevia dentro de uma perspectiva delimitada pelo discurso que fazia incidência sobre ele, fazendo, assim, nome.

Ao dar lugar às letras de seu nome, é o sujeito mesmo que articula a si e aos seus em um encadeamento onde a linguagem é o cenário. Curiosamente, é justo no momento em que algo está fora do lugar na escrita do nome próprio que um sujeito demonstra o quanto está mergulhado na língua.

O tempo em que o sujeito circunscreve os traços que vão dar contorno às letras tipográficas é também testemunho de que seu corpo já constitui bordas suficientes e pode cair, pois só podemos escrever quando esquecemos os movimentos que se precisa fazer. Se a escrita, de certa forma, pode implicar em uma certa estabilização do sujeito capaz de escrever seu nome como um signo de identidade, como aponta Emilia Ferreiro, é na escrita, enquanto ruptura e releitura das origens, onde podemos encontrar um sujeito. Entre a transmissão de um nome próprio e sua apropriação, na configuração de um próprio ao nome, precisa-se passar por uma operação de escrita, de uma escrita que dá lugar à falta, ao apagamento e à rasura, pois é justamente aí - quando o lugar vago permite o exercício de seu preenchimento - que uma transmissão opera. É necessário entreler, ler nas entrelinhas da escrita do nome próprio algo de uma singularidade, articulando o universal da tradição com o particular de uma versão, para percebermos que não há insuficiência de linguagem, mas que é, justamente, ao deixar cair letras (BERGĖS \& BALBO, 1997) que um sujeito pode advir. Então, se por um lado, é na escrita do nome que transparecem as posições subjetivas ocupadas no trânsito entre o nome próprio e o próprio nome, é em sua leitura que reside a condição para que a passagem se realize.

\section{BIBLIOGRAFIA}

BALBO, Jean. Do ouvido ao olho, e num estalar de dedos - acerca do desenho e de sua leitura prévia para interpretá-lo. In: TEIXEIRA, Ângela B. do Rio (org.) O mundo a gente traça - considerações psicanalíticas acerca do desenho infantil. Salvador: Ágalma, 1991.

BERGĖ, Jean \& BALBO, Gabriel. A criança e a psicanálise. Porto Alegre: Artes Médicas, 1997.

FERREIRO, Emilia \& TEBEROSKY, Ana. Psicogênese da lingua escrita. Porto Alegre: Artes Médicas, 1999.

JERUSALINSKY, Alfredo. Seminários III. São Paulo: Universidade de São Paulo, 2004.

JESUINO-FERRETO, Ângela. Le Patronyme au Bresil : quelle fonction? In: Le Trimestre Psychanalytique. Le Patronyme. Publication de L'Association Freudienne. Paris, 1992.

LACAN, Jacques. [1957] A instância da letra no inconsciente ou a razão desde Freud. In: Escritos. Rio de Janeiro: Zahar, 1998.

. [1967] Proposição de 9 de outubro de 1967. In: Outros Escritos. Rio de Janeiro: Jorge Zahar Editor, 2003. . [1972-1973] Mais, ainda. 2aed. Rio de Janeiro: Zahar, 1985.

MARTINS, Francisco. O nome próprio. Brasília: UNB, 1991.

SAUSSURE, Ferdinand de. Curso de Lingüística Geral. São Paulo: Cultrix, 2003. 